\title{
DETERMINING THE EFFECTIVENESS OF PROPOSED CUSTOMIZED FINANCIAL SOFTWARE IN A PUBLIC SECTOR UNIVERSITY
}

Muneer A. Shaikh

Mehran University of Engineering and Technology, Pakistan.

E-mail: munir.shaikh@admin.muet.edu.pk

Rizwan Hassan

Mehran University of Engineering and Technology, Pakistan.

E-mail:rizwanmtc@gmail.com

Mujawar Malik

Mehran University of Engineering and Technology, Pakistan.

E-mail: mujawar2@gmail.com

Ali Akbar Shah

Mehran University of Engineering and Technology, Pakistan. E-mail: shah.aliakber32@gmail.com

Recepción: 30/07/2019 Aceptación: 20/09/2019 Publicación: 06/11/2019

\section{Citación sugerida:}

Shaikh, M.A., Hassan, R., Malik, M. y Shah, A.A. (2019). Determining the effectiveness of proposed customized financial software in a Public Sector University. 3C Tecnología. Glosas de innovación aplicadas a la pyme. Edición Especial, Noviembre 2019, 149-165. doi: http:// dx.doi.org/10.17993/3ctecno.2019.specialissue3.149-165

\section{Suggested citation:}

Shaikh, M.A., Hassan, R., Malik, M. \& Shah, A.A. (2019). Determining the effectiveness of proposed customized financial software in a Public Sector University. 3C Tecnologia. Glosas de innovación aplicadas a la pyme. Speciaal Issue, November 2019, 149-165. doi: http:// dx.doi.org/10.17993/3ctecno.2019.specialissue3.149-165 


\section{ABSTRACT}

Professionals all around the globe use various available software products for the data solutions of their firm. These software products are general and are available publically. But in order to develop customized software, huge amount of money and efforts are needed. Therefore in this proposed paper, a budget friendly software based on basic business infrastructure of accounting in finance is developed. The contribution of the software is in PV payments, inspection of personal ledger accounts, ledger reports and summary of various vouchers as well as it can fetch and print the details of the cheques as well. In the result section of this paper a survey is conducted for showcasing the effectiveness and importance of this software.

\section{KEYWORDS}

Software products, Customized software, Budget friendly software, Accounting, PV payments, Ledger accounts, Ledger reports, Voucher, Cheque, Survey. 


\section{INTRODUCTION}

Various software products are available in the open source and licensed that have applications in accounting and finance (Hoefler et al., 2012; Cook, 2017; Ryan, Scapens, \& Theobald, 2002; Atanasov \& Black, 2016; Bangemann, 2005). Software products like Oracle, SPSS, Peachtree, SAAS and Microsoft excel are at the pinnacle of the software products chart based on business applications (Beckett, Castagno, Lockwood, \& Mcdougald, 2017). Whereas, in terms of customization SAP is at very best of its game (Lorenc \& Szkoda, 2015). Modules like SAP Hana provide user friendly interface to its customers but the problem with these software products like SAP is its pricing (Cook, 2017; Rasmussen, Goldy, \& Solli, 2002). SAP modules are very expensive therefore it is not possible for the companies with less financial backing to afford them. So for overcoming this problem, a new software solution is required that has similar user friendly interface like the SAP (Driesen, Engelko, Jahr, Muscarella, \& Storz, 2015).

The main problem with the development of the software is its architecture, user interface and back coding (Yousouf \& Stanev, 2015). Moreover, it must also contain applications that are essential for the operation of the enterprises (Rogaway \& Coppersmith, 1998). Basic accounting software requires many functionalities and data tools for analyzing the company's data as well its interface must be properly encrypted so that a third party cannot access the classified data. Encryption plays a vital role in securing the data and in preventing the online attacks. Attacks like Ransomware had taken most of the multinational firms with the threat of hacking their most sensitive data (Kharraz, Robertson, Balzarotti, Bilge, \& Kirda, 2015; Kharaz, Arshad, Mulliner, Robertson, \& Kirda, 2016). So it is the task of the software developers to understand the risks of the software development and any loophole in the software development can be have fatal outcomes. 


\section{SYSTEM FLOW}

The system flow diagram of the proposed software is mentioned in the below Figure 1 :

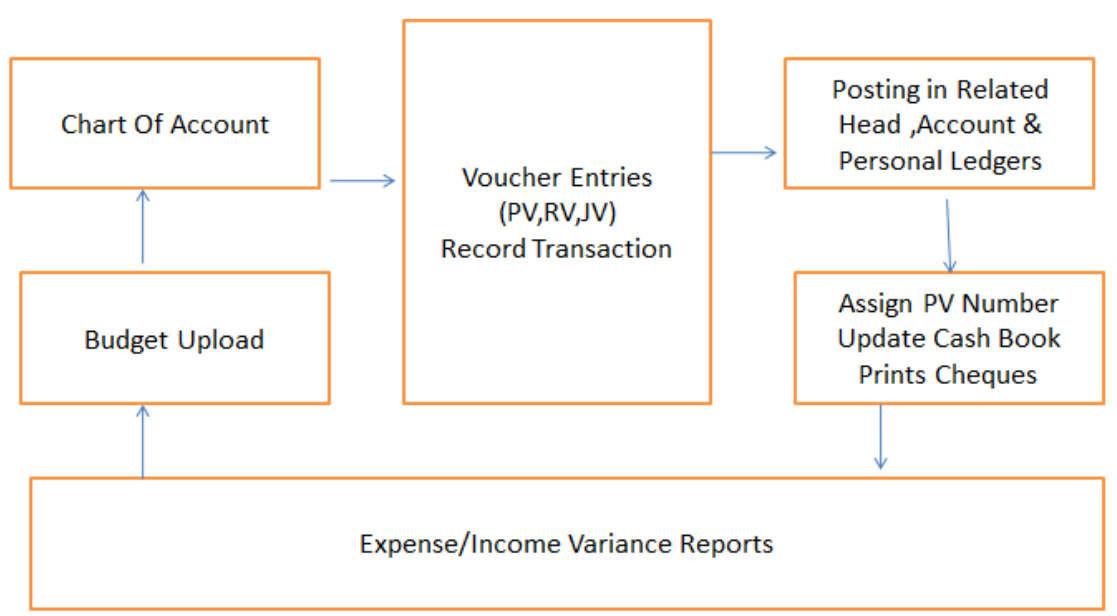

Figure 1. Signal Flow Chart.

In the above Figure 1, it is clearly illustrated that the details of the account are linked with the voucher entries that are basically the transactions that are made by the user. These transactions are being recorded. After this process, the software fetches the details of the transactions and to whom it is being sent. After the process of sender classification is finished then the transaction is moved to designated head of that specific department. After approval of those transactions by the head, each of the transactions is assigned with a unique PV number and later the cheque is printed. With the completion of this process, the cheque books are updated automatically by the software.

This software also provides data analysis tools like the income variance report that shows the variations in the withdrawal of the transactions whereas the remaining budget is updated accordingly to the account sheets. 


\section{NETWORK TOPOLOGY}

Star topology is implemented by connecting the end users with a common server that is shown in the figure below:

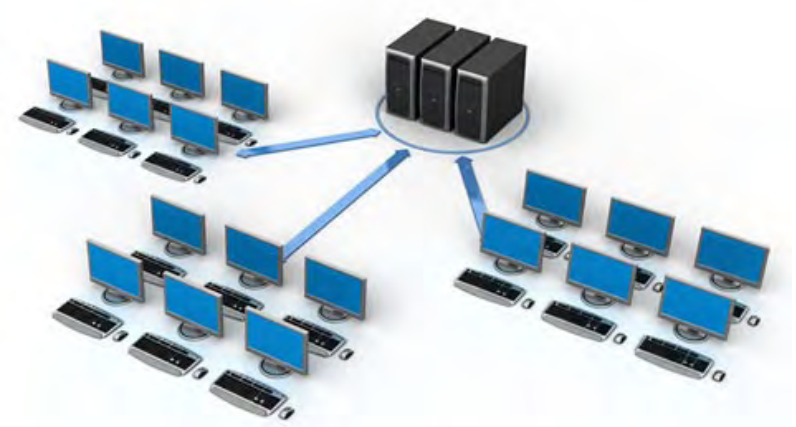

Figure 2. Star Network Topology.

The end user can access the server with the local domain IP which can be accessed by the end users that relate to the common network connection. WPA/WPA2 PSK protocol of the network is implemented for accessing the local server that requires the username and password which will be given by system administrator to the end users. Moreover keeping the security into consideration the variations in the software can only be controlled by the master administrator.

\section{WORKING OF THE SOFTWARE}

\subsection{CHART OF ACCOUNT}

A separate chart of the account is prepared based on each designation in which the employee is employed on. Various allowances and charges are incorporated based on the designations. These charts of the account are then allocated with specific number for their classification based on the grades of the employees. A sample account chart is shown in the mentioned below figure: 


\begin{tabular}{|c|c|c|}
\hline & \multicolumn{2}{|c|}{ Mehran University of Engineering and Technology, Jamsh } \\
\hline & \multicolumn{2}{|c|}{ CHART OF ACCOUNT } \\
\hline \multicolumn{2}{|c|}{ Account Type } & \multirow[t]{2}{*}{ HEC Code } \\
\hline $05-03-022-0026$ & Quality Coordinator Allowance & \\
\hline $05-03-022-0027$ & Leave Salary / Pension Contribution & A0127801 \\
\hline \multicolumn{3}{|c|}{ Teaching Department (Allied Staff) -Other Allowances } \\
\hline $05-03-022-0028$ & Leave Salary & A0127801 \\
\hline \multicolumn{3}{|c|}{ Teaching Department (Allied Staff) -Other Regular Allowances } \\
\hline $05-03-022-0029$ & Adhoc. R Allowance $2015-10 \%$ & A012091 \\
\hline $05-03-022-0030$ & Adhoc.R Allowance $2016-10 \%$ & A012091 \\
\hline \multicolumn{3}{|c|}{ Teaching Department (Allied Staff) -Other Allowances } \\
\hline 05-03-023-0001 & Overtime Allowance to Drivers & $\mathrm{A} 01271$ \\
\hline $05-03-023-0002$ & Night Duty Allowance & $\mathrm{A} 01272$ \\
\hline $05-03-023-0003$ & Honorarium & $\mathrm{A} 01273$ \\
\hline $05-03-023-0004$ & Medical Charges - Ho spitalization etc. & $\mathrm{A} 01274$ \\
\hline $05-03-023-0005$ & Contingent Paid Staff / Daily Wages & $\mathrm{A} 01277$ \\
\hline $05-03-023-0006$ & Teaching Allowance/Technical Allowance & A01289 \\
\hline $05-03-023-0008$ & Group Insurance & $\mathrm{A} 0127802$ \\
\hline $05-03-023-0009$ & Others (Leave Encashment) & $\mathrm{A} 01275$ \\
\hline $05-03-023-0010$ & Bills Payable & $\mathrm{A} 0127804$ \\
\hline $05-03-023-0011$ & Payment of Difference (Pay Allow \& Others) & $\mathrm{A} 01290$ \\
\hline \multicolumn{3}{|c|}{$\begin{array}{l}\text { Establishment Charges Others } \\
\text { Other Establishment Charges }\end{array}$} \\
\hline $05-04-024-0001$ & Honorarium (OEO) & $\mathrm{A} 01273$ \\
\hline $05-04-024-0002$ & Medical Charges - Hospitalization etc (OEQ) & $\mathrm{A} 01274$ \\
\hline $05-04-024-0003$ & Group Insurance (OEC) & $\mathrm{A} 0127802$ \\
\hline $05-04-024-0004$ & Other (Leave Encashm ent) (OEO & $\mathrm{A} 01275$ \\
\hline
\end{tabular}

Figure 3. Account Chart.

As this software is designed for an educational institution so for each allowances and charges, a unique HEC code is allocated.

\subsection{ALLOCATION OF THE BUDGET}

The budget that is allocated by the institution is then feed on the proposed software along with the HEC codes. The software is capable enough of the updating the amount of the budget once the money is withdrawn or is transferred to the account as shown in the figure below: 
Edición Especial Special Issue Noviembre 2019 DOI: http://dx.doi.org/10.17993/3ctecno.2019.specialissue3.149-165

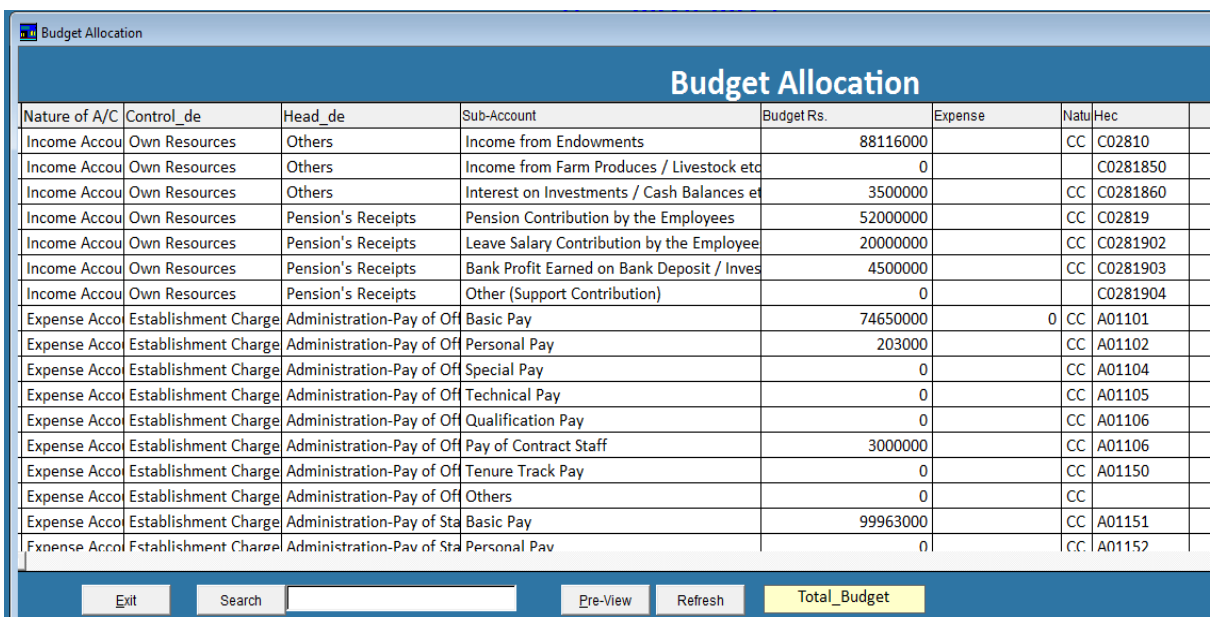

Figure 4. Budget Allocation Sheet.

\subsection{VOUCHERS AND TRANSACTION RECORDS}

After the prerequisites are fulfilled after feeding the numeric needed for the budget allocation and account charts, then vouchers are made for keeping the record of the account based on the budget of the project and the salaries that awarded to the project team members as shown in the figure below:

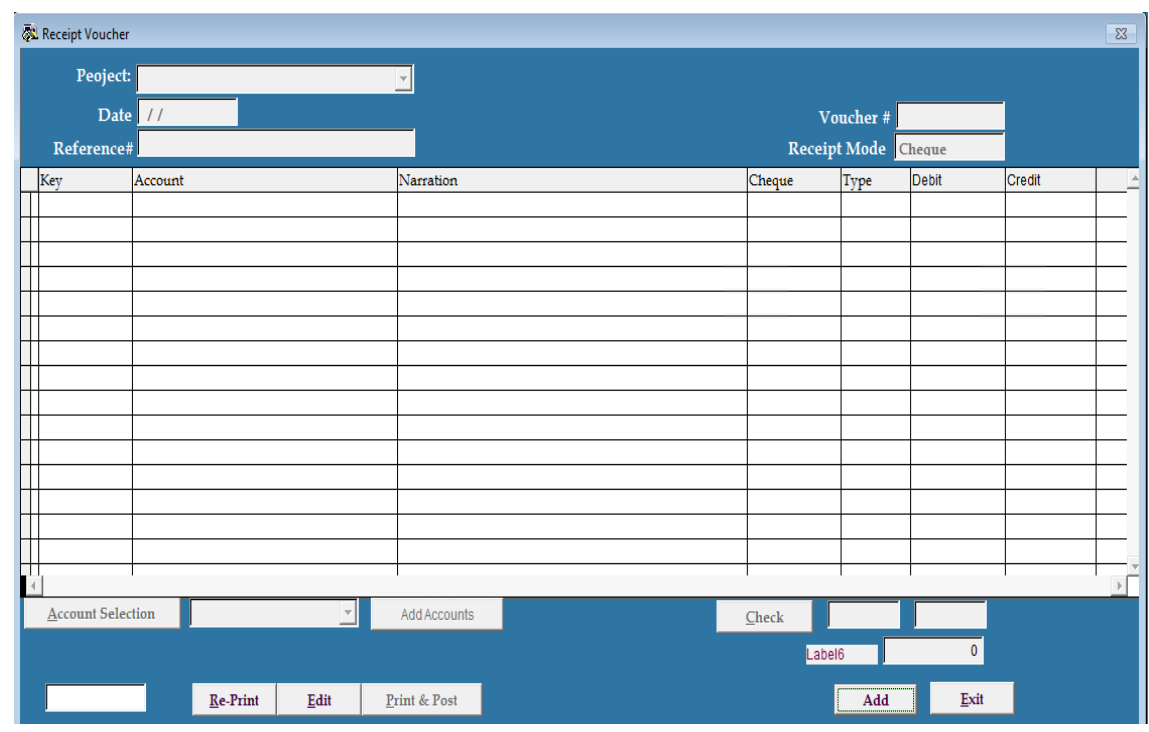

Figure 5. Voucher Sheet. 
After the saving the data of the vouchers in the proposed software, the software provides various customized options that include cost of the project, reference number for the transaction, account key, account title, details of the bank transactions, etc. as shown in the mentioned below figure:

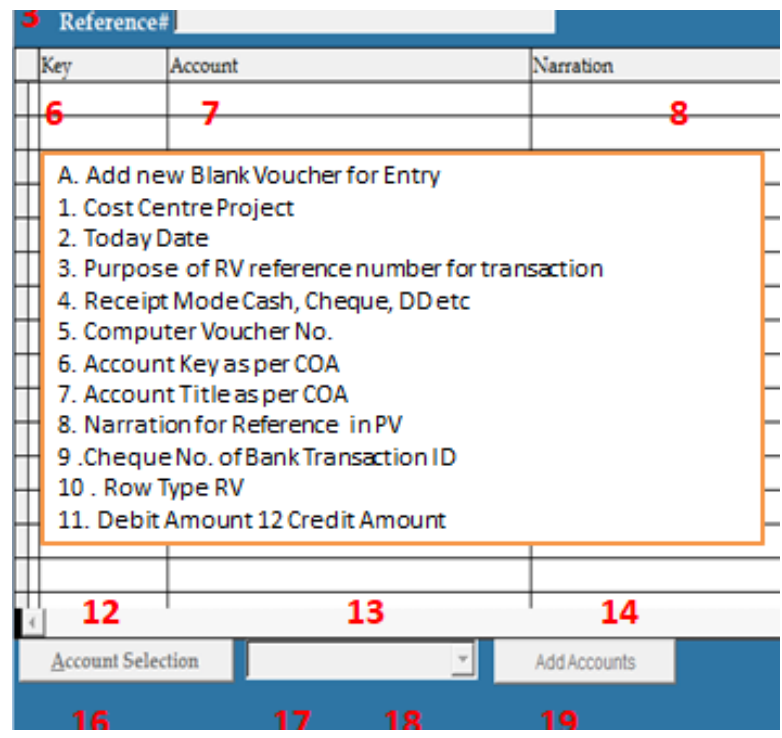

Figure 6. Software Options.

This business transaction records are present in the account ledger which can be accessed by the user and it contains all the necessary data of the transaction that are done previously as shown in the figure below:

\begin{tabular}{|c|c|c|c|c|c|}
\hline \multirow{4}{*}{ (1) } & & \multicolumn{4}{|c|}{ Mehran University of Engineering and Technology, Jamshoro. } \\
\hline & & \multicolumn{4}{|l|}{$\underline{\text { Account Ledger }}$} \\
\hline & \multirow[t]{3}{*}{$05-05-0$} & Registration & & \multirow{2}{*}{$\begin{array}{r}\text { Page \# : } \\
\text { Print Date : }\end{array}$} & 001 \\
\hline & & Complete Ledger & & & $17 / 05 / 17$ \\
\hline Ref\# & & Description & Debit & Credit & Balance \\
\hline $\begin{array}{|ll|}P V-28 & P V \\
\end{array}$ & 8 Jul 15 & $\begin{array}{l}\text { Peimbusement Paid to Mr. Fiaz Hassan Quershi For Notor Vehide } \\
\text { Annual Tax3 Nos Veh: Nos GL-7038, GL No.7051 \& GSB-986 for the } \\
\text { year }\end{array}$ & \begin{tabular}{l|l|}
$1,900.00$ &
\end{tabular} & & $1,900.00 \mathrm{DB}$ \\
\hline$=$ PV-3599 PV & 22 Ma 16 & \begin{tabular}{|l|} 
Reimbursement Paid to Mr. Fiaz Hassan Quershi for the Registration \\
02 Uni: Veh: No GS0659,FA-8922, \& GSC. 545 \& CU 9892
\end{tabular} & $60,500.00$ & & $62,400.00 \mathrm{DB}$ \\
\hline PV-4049 & 21 Apr 16 & Dif: Sal. of Mr. Ali Asghar & & & $62,400,00 \mathrm{DB}$ \\
\hline & & Total Amount : & $62,400.00$ & & $-62,400.00$ \\
\hline
\end{tabular}

Figure 7. Sample Account Ledger. 
Whereas, the voucher summary based on the financial budget of the project can also be viewed as shown below:

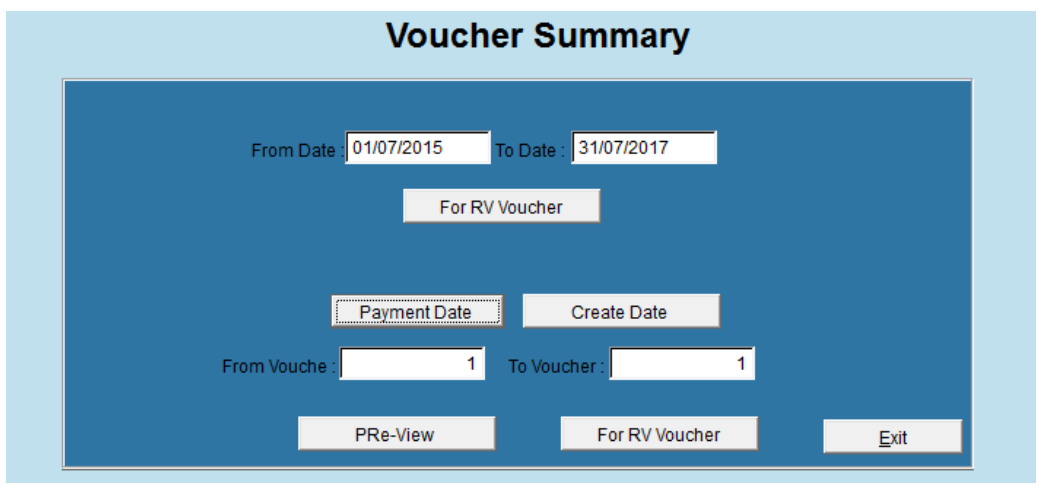

Figure 8. Voucher Summary.

Based on these records, the cheques can be later printed with the reference to the chart of the account and allocation of the budget as shown below:

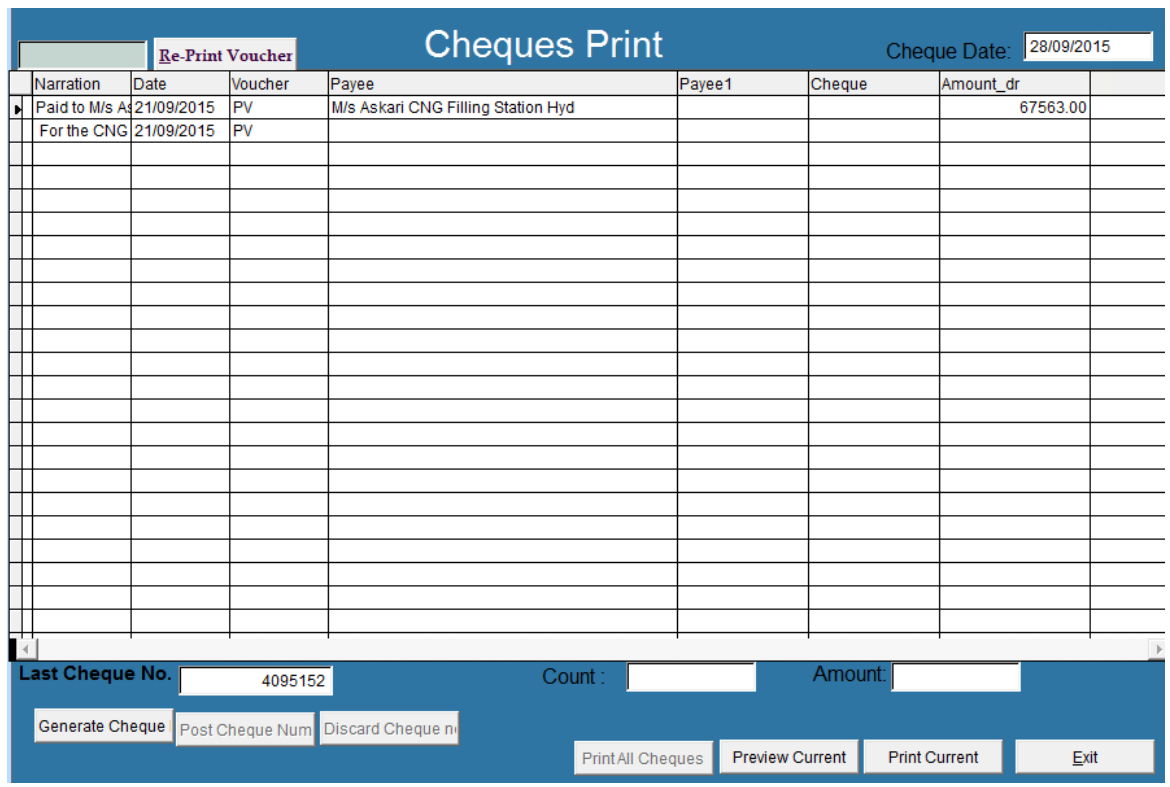

Figure 9. Cheque Print Sheet.

While the receipt can be also viewed along with the variance report of the profit and expense of the project as shown below: 


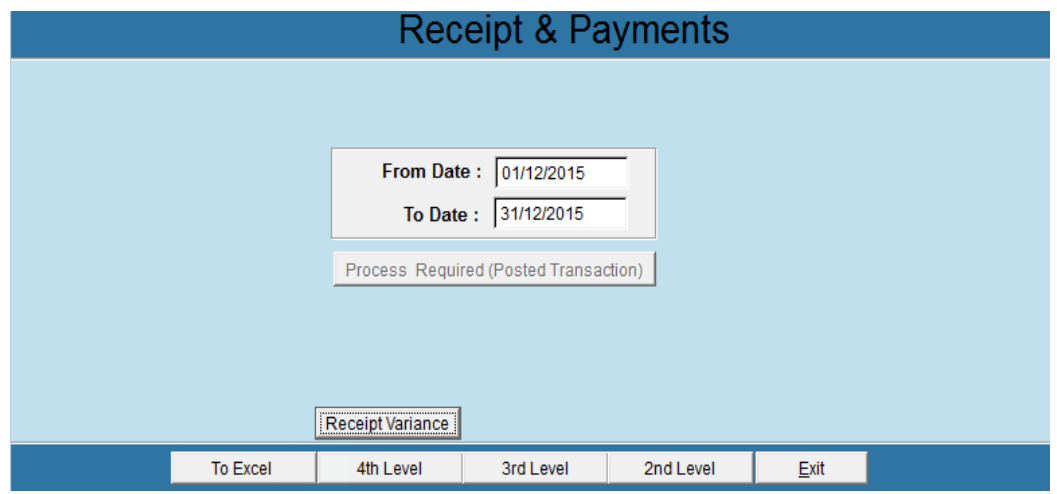

Figure 10. Receipt and Payment.

In order to demonstrate the effectiveness of the personal record of a voucher, the personal ledger of a sample is shown as below:

\section{$\underline{\text { Personal Ledger }}$}

\section{M/s TCS Private Ltd.}

Page \# : 001

Date : $17 / 05 / 17$

\begin{tabular}{|c|c|c|c|c|c|c|}
\hline Date & Vou \# & Narration & Account & Debit & Credit & Balance \\
\hline \multicolumn{2}{|c|}{13 Jul 15 PV -74} & $\begin{array}{l}\text { Payment Paid to Ms Tos Put Ltd Office of the } \\
\text { V.C Secett: for the month of June } 2015\end{array}$ & Courier And Flot Services & 237 & & 237) \\
\hline \multicolumn{2}{|c|}{13 Jul 15 'PV -76} & $\begin{array}{l}\text { Payment Paid to M/s Tes PvtLtd office of the } \\
\text { REgistrar for the month of June } 2015\end{array}$ & Courier And Plot Services & 5,702 & & ( 5,939$)$ \\
\hline \multicolumn{2}{|c|}{23 Jul 15 PV-155 } & $\begin{array}{l}\text { Payment Paid to M/s Tes PvtL to for the month of } \\
\text { June } 2015 \text { office of Director Works }\end{array}$ & Courier And Hlot Services & 2,286 & & ( 8,225$)$ \\
\hline \multicolumn{2}{|c|}{6 Avg 15 PV-284 } & $\begin{array}{l}\text { Payment Paid to M/s Tcs PutLtd For the month } \\
\text { of June } 2015 \text { Controller of Exam: }\end{array}$ & Courier And Flot Services & 7,771 & & ( 15,996$)$ \\
\hline \multicolumn{2}{|c|}{6 Aug 15 PV-285 } & $\begin{array}{l}\text { Payment Paid to M/s Tes Pvt Ltd For The month } \\
\text { of June } 2015 \text { Controller Exam: Bill No } \\
\text { HD211004 }\end{array}$ & Courier And Flot Services & 17,064 & & ( 33,060$)$ \\
\hline \multicolumn{2}{|c|}{7 Aug 15 PV-313 } & $\begin{array}{l}\text { Payment Paid to M/s Tcs PvtLtd For the month } \\
\text { of bill July } 2015 \text { from V.C Secretariat }\end{array}$ & Courier And Hlot Services & 418 & & ( 33,478$)$ \\
\hline \multicolumn{2}{|c|}{11 Aug 15 PV-344 } & $\begin{array}{l}\text { Payment Paid to M/s Tcs PvtL td For the office of } \\
\text { Registrar month of July } 2015\end{array}$ & Courier And Flot Services & 4,941 & & ( 38,419$)$ \\
\hline \multicolumn{2}{|c|}{17 Aug 15 PV- -420} & $\begin{array}{l}\text { Payment Paid to M/S TCS PvtL to for the month } \\
\text { of July } 2015 \text { Bi1N0-HDD212662 Dt:31/7/2015 }\end{array}$ & Courier And Plot Services & 2,474 & & ( 40,893$)$ \\
\hline \multicolumn{2}{|c|}{25 Aug 15 PV -505} & $\begin{array}{l}\text { Payment Paid to M/s TCS Put Ltd for the of } \\
\text { month July } 15 \text { office of controller Exam }\end{array}$ & Courier And Flot Services & 8,292 & & ( 49,185$)$ \\
\hline \multicolumn{2}{|c|}{26 Aug 15 PV- 531} & $\begin{array}{l}\text { Payment Paid to M/s TCS PvtLtd: For The } \\
\text { month of July } 2015 \text { from Controller Exam: }\end{array}$ & Courier And FlotServices & 6,890 & & ( 56,075$)$ \\
\hline \multicolumn{2}{|c|}{14 Sep 15 PV-766 } & $\begin{array}{l}\text { Payment Paid to M/s Tcs PvtL td For the month } \\
\text { of August } 2015 \text { Office of director works \& } \\
\text { services }\end{array}$ & Courier And Flot Services & 2,348 & & ( 58,423$)$ \\
\hline
\end{tabular}

Figure 11. Sample Personal Ledger Sheet. 


\section{RESULTS}

The performance of the software was tested based on the survey conducted from the end users that are currently using the proposed software. First and foremost the installation and the compatibility of the software with the hardware were concerned. The bar graphs of the survey are shown in the Figure 12 and Figure 13, respectively. The survey was taken of 20 employees that were also the end users of the proposed software. Majority of them expressed their satisfaction towards the installation of the software.

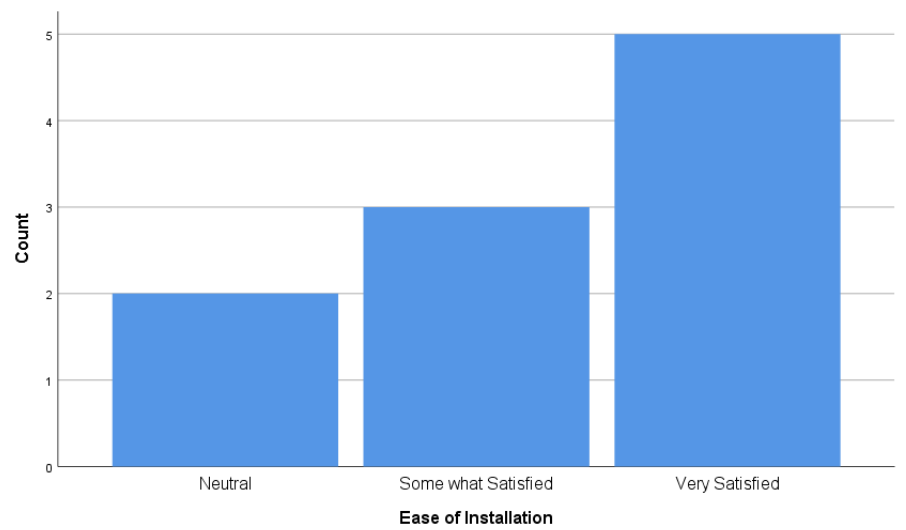

Figure 12. Survey of Ease of Installation.

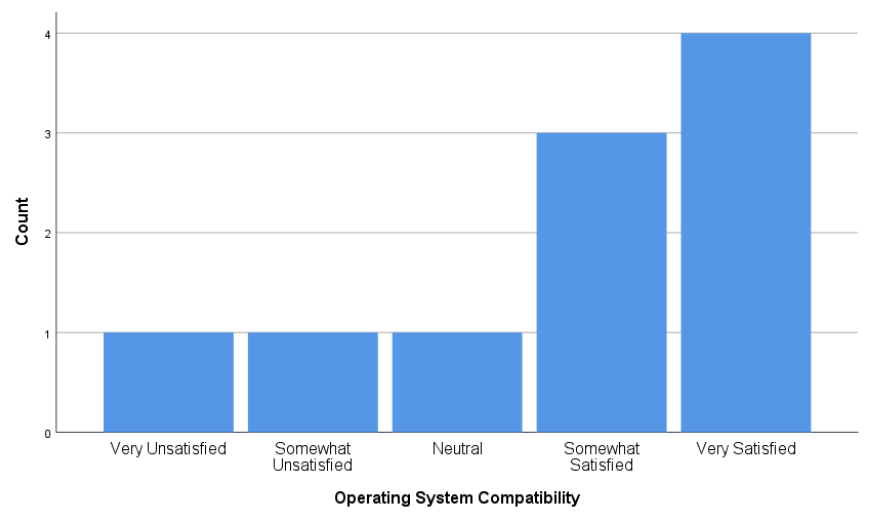

Figure 13. Survey of Operating System Compatibility.

The second most important issue of the financial software is the completeness of the needed tools and clarity in the documentation. In the survey of this, majority of the 
end users were satisfied with the completeness of the needed tools and clarity of the proposed documentations as shown in the mentioned below Figure 14 and Figure 15 , respectively.

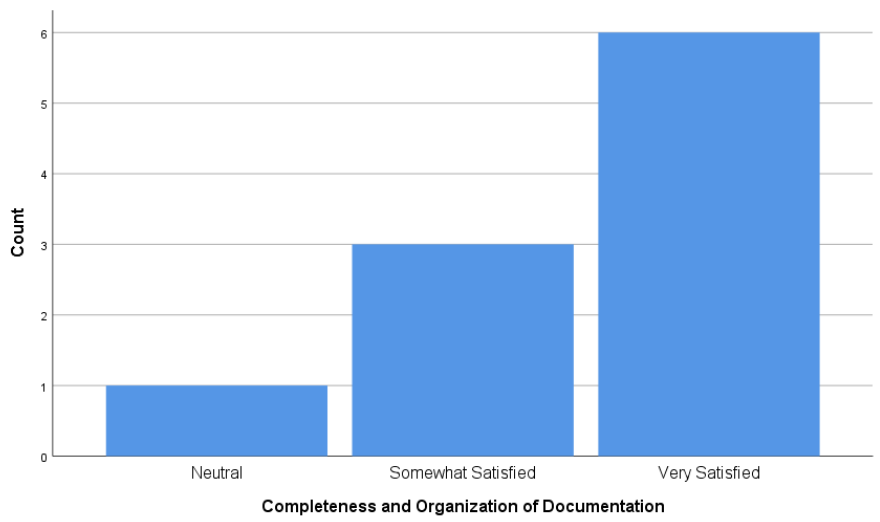

Figure 14. Survey of Completeness and Organization of the Data.

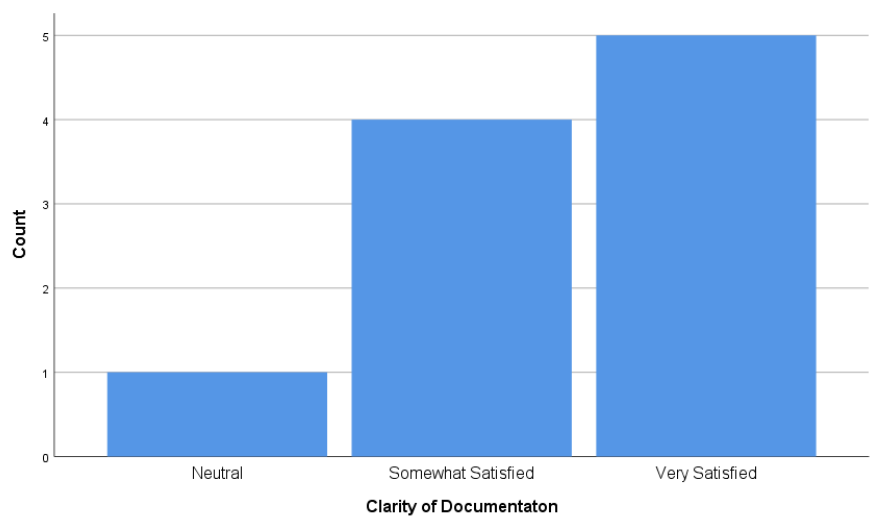

Figure 15. Survey of Clarity of Documentation.

While considering the quality of the software support most of the end users were somewhat satisfied as shown in the below Figure 16. But as the software is at its initial stage and it is new in comparison with the legacy software so therefore the end users had certain problems, dealing with the software interface support environment. 


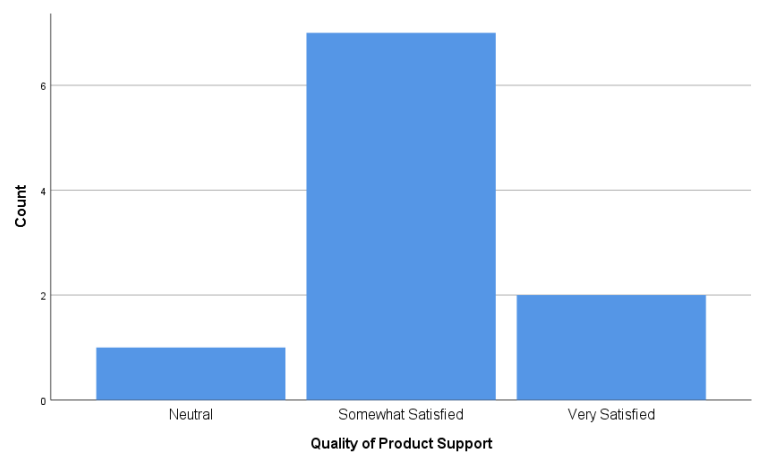

Figure 16. Survey of Quality of Product Support.

Moreover the software was stated to be very cost efficient and reliable. The end users as shown in the survey mentioned in the below Figure 17 were quite satisfied with the overall cost of the software in comparison with the software products that are already available in the market. Where as in the reliability as shown in the survey mentioned in the figure, almost all the end users claimed that their none of the data was lost nor any reports of the software crashed where been recorded by any of the end user.

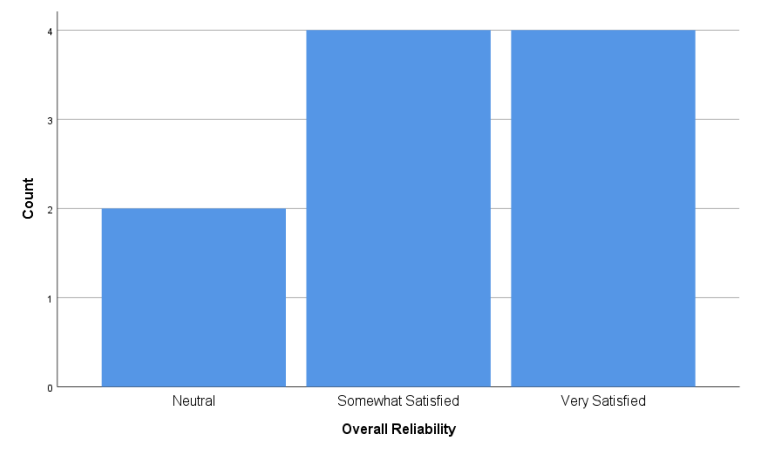

Figure 17. Survey of Software Reliability.

\section{CONCLUSION}

Considering the overall performance of the software which is mentioned in the mentioned below Figure 18 that is the survey of the end users, almost all the end users had expressed their satisfaction as shown in the survey mentioned in the Figure 19. 


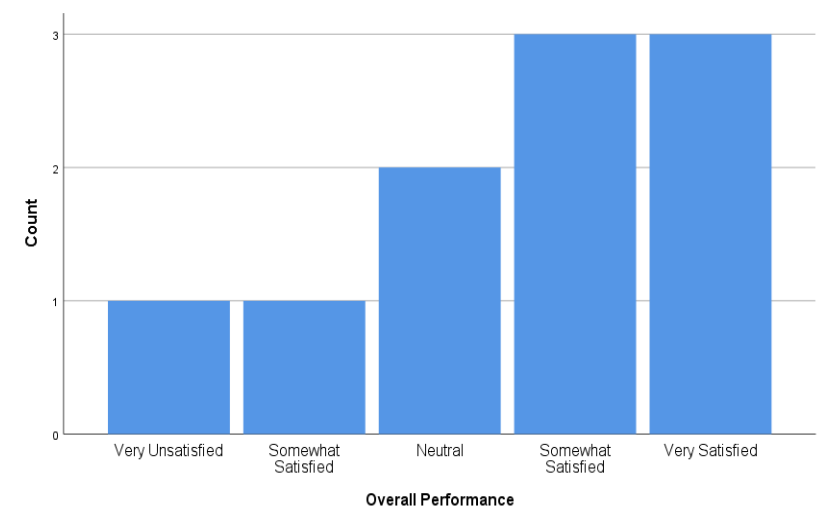

Figure 18. Survey of Overall Software Performance.

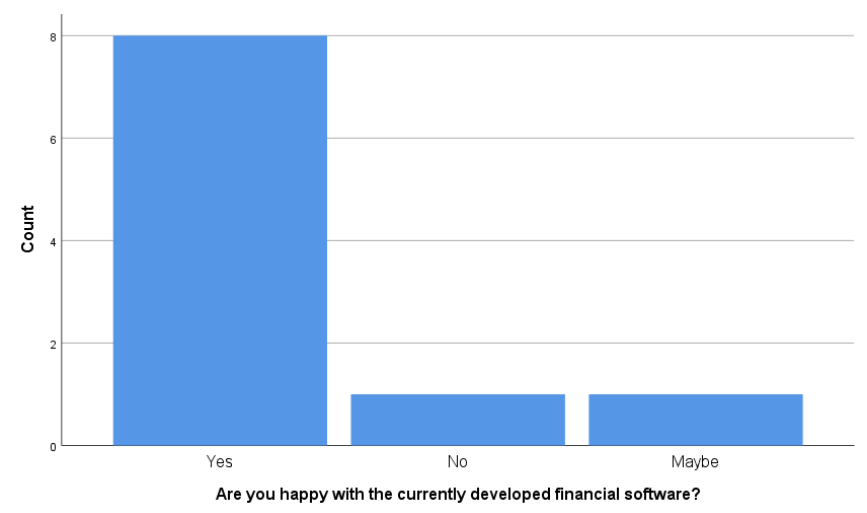

Figure 19. Customer Satisfaction Survey.

As well as most of the end users had agreed on proclaiming this proposed software to be better and more budget friendly than the other software products that are currently available in the market as shown in the Figure 20 and Figure 21 below: 


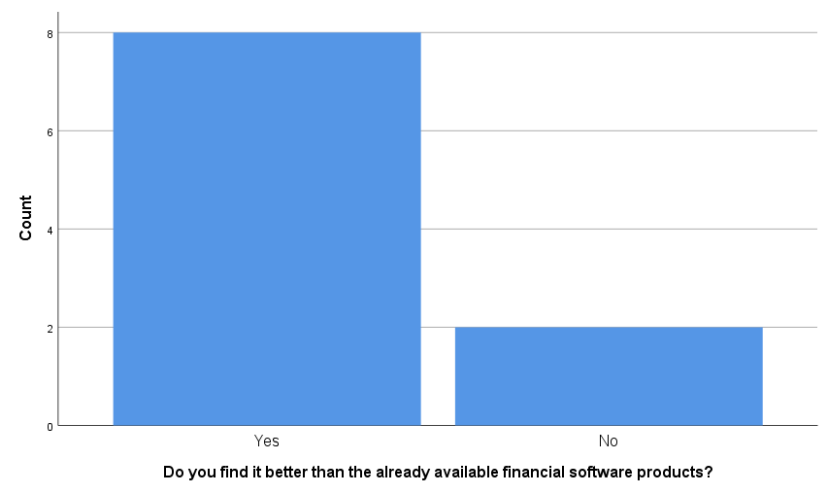

Figure 20. Survey of Optimization.

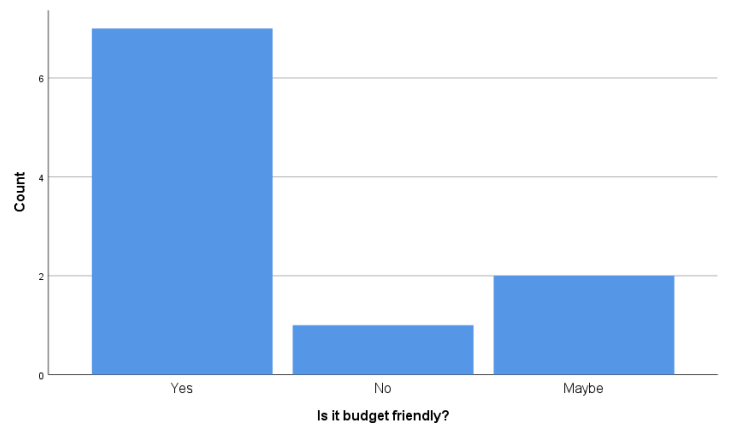

Figure 21. Survey of Cost Efficiency.

\section{ACKNOWLEGEMENT}

We are highly indebting of the Finance department of MUET and its employees for testing the software and Mr. Mujawar Malik without whom this software wouldn't have been possible.

\section{REFERENCES}

Atanasov, V. A., \& Black, B. S. (2016). Shock-based causal inference in corporate finance and accounting research. Critical Finance Review, 5, 207-304. doi: http:// dx.doi.org/10.1561/104.00000036 
Bangemann, T. O. (2005). Shared services in finance and accounting. Gower Publishing, Ltd.

Beckett, S. M., Castagno, A. J., Lockwood, D. G., \& Mcdougald, H. D. (2017, September 19). System and method for non-programmatically constructing software solutions. Google Patents.

Cook, N. (2017). Enterprise 2.0: How social software will change the future of work. Routledge.

Driesen, V., Engelko, A., Jahr, A., Muscarella, F., \& Storz, G. (2015, November 17). Software logistics protocols. Google Patents.

Hoefler, D., Jansen, J., Stegmueller, H., Karolin, L., Chen, X., Wang, C., \& Bai, X. (2012, May 8). Software maintenance management. Google Patents.

Kharaz, A., Arshad, S., Mulliner, C., Robertson, W., \& Kirda, E. (2016). UNVEIL: A Large-Scale, Automated Approach to Detecting Ransomware. 25th USENIX Security Symposium (USENIX Security 16), 757-772.

Kharraz, A., Robertson, W., Balzarotti, D., Bilge, L., \& Kirda, E. (2015). Cutting the gordian knot: A look under the hood of ransomware attacks. International Conference on Detection of Intrusions and Malware, and Vulnerability Assessment, 3-24. Springer. Retrieved from: https://seclab.ccs.neu.edu/static/publications/ dimva2015ransomware.pdf

Lorenc, A., \& Szkoda, M. (2015). Customer logistic service in the automotive industry with the use of the SAP ERP system. 2015 4th International Conference on Advanced Logistics and Transport (ICALT), 18-23. IEEE.

Rasmussen, N. H., Goldy, P. S., \& Solli, P. O. (2002). Financial business intelligence: trends, technology, software selection, and implementation. John Wiley \& Sons.

Rogaway, P., \& Coppersmith, D. (1998). A software-optimized encryption algorithm. Journal of Cryptology, 11(4), 273-287. doi: https://doi.org/10.1007/ s001459900048 
Ryan, B., Scapens, R. W., \& Theobald, M. (2002). Research method and methodology in finance and accounting. Retrieved from: https://pdfs.semanticscholar.org/ f5b8/78307fc6c8a2139a9c2265c28894b41d1847.pdf

Yousouf, S., \& Stanev, G. (2015, June 23). Deployment of software applications on a cloud computing platform. Google Patents. 